Per V. Freytag, Pia Storvang*

\title{
Dynamics of a facilitator's role: Insights from the Danish construction industry ${ }^{* *}$
}

A facilitator is used in many different business capacities. In the construction industry, the role of facilitator is usually carried out by a stakeholder, often the architect. Facilitation embodies different roles, competences and activities. The present research addresses how a facilitator may have and make use of different roles during different phases of a process. This paper is based on a theory-building approach that combines existing theory and cases. Three cases demonstrate other stakeholders' involvement in the process and the impact of this involvement on the facilitator's role. The research in the three cases applied is based on workshops, interviews and observations. The cases are viewed from role and network perspectives, offering both possibilities and limitations for innovations in different stages of construction projects. Construction process facilitators fill the role of assisting and enabling the process. To achieve project success, they align the activities of various stakeholders. They reach alignment by influencing the other stakeholders, based on competences and the role taken and made. This paper contributes to the understanding of the facilitator's role, the changes in this role over time and this role's importance in construction industry projects.

Key words: facilitation, roles, involvement, construction, contingencies, alignment

(JEL: L22, L24, L74, L85, M39, M59, O22)

* Per V. Freytag, University of Southern Denmark, Department of Entrepreneurship and Relationship Management, Engstien 1, DK-6000 Kolding, Denmark.

E-mail:pvf@sam.sdu.dk.

Pia Storvang, University of Southern Denmark, Department of Entrepreneurship and Relationship Management, Engstien 1, DK-6000 Kolding, Denmark.

E-mail:spi@sam.sdu.dk.

** Article received: April 7,, 2014

Revised version accepted after double blind review: March 2, 2016. 


\section{Introduction}

This paper addresses the role of a facilitator in achieving project goals in business. A facilitator is widely used in business practice to help processes or projects evolve under various conditions. We use the construction industry as a stepping stone to learning more about facilitation, as a facilitator is often used in construction projects (Christiansson, Sørensen, Rødtness, Abrahamsen, Riernnann, \& Alsdorf, 2008; Storvang \& Clarke, 2014). In the construction industry, many stakeholders (architects, engineers, consultants, builders, etc.) are often involved in carrying out-and sometimes even developing - a number of tasks. The various stakeholders might have worked together on previous projects, but this is not necessarily the case. Just as a building's intended use can vary from project to project, the aims, interests, resources and competences of individual stakeholders involved in a construction project can also vary. Aligning all these factors can be a challenge, and failure to do so could put a project at risk of moving slowly or even stalling (Corsaro \& Snehota, 2011). To ensure projects advance properly, it is common to facilitate the process. Facilitation is a means to ensuring that all aspects of a project are investigated, defined, described, developed and delivered. In the facilitation process, alignment is essential (Guzman, 2013). We define alignment in accordance with Corsaro and Snehota (2011), who claim that actors may hold different understandings of what constitutes "a problem" and "a solution". Actors can therefore be misaligned or position themselves according to their own perception of a problem and/or its solution. The facilitator's task is to achieve alignment in such a manner that the project can proceed and be finalised. As content and processes vary among construction projects, so do the requirements for facilitation. In turn, these variations require different competences from the stakeholder who is acting as the facilitator. Even so, it has been demonstrated that facilitation of construction projects is beneficial (Shen, Li, Chung, \& Hui, 2003; Thomson, Kaka, Pronk, \& Alalouch, 2012; Thomson, Kaka, Pronk, \& Alalouch, 2010).

This paper seeks to explore how different contingencies influence the facilitator's role and to develop a framework that can be used to analyse the different tasks and competences needed in the role of facilitator. The paper is organised into five sections. The first section includes a discussion of the contingencies related to the states around which construction projects evolve and the implications for facilitation. Next, a methodology section reveals the reason for the selection of the three cases. Three cases are presented: an extension to an existing single-family house, guest houses for an exhibition and conference complex and an office-building complex. A discussion of the three cases follows, succeeded by conclusions and implications.

\section{Contingencies in construction projects, as seen from an interaction perspective}

Construction projects are developed under certain contingencies; in addition to having different uses, they also vary in terms of content, processes and stakeholders (Eccles 1981). The view of the different construction projects is therefore based on a contingency approach (Barney 1985). In order to enable progress in construction projects and come to a successful end, alignment is necessary. The goals, functions, timing, 
identities, roles, processes and power relations of the stakeholders must be taken into account (Guzman, 2013). As such alignment is not necessarily reached by itself, facilitation of the process becomes a necessary course of action. Still, construction projects vary not only with regard to their contingencies but also as to which issues are at stake at different points in time. At a basic level, building a construction can be said to include a number of phases (Clausen, 2002; Storvang, 2012). The decision of whether to build can be seen as the feasibility study and the first phase of a construction project. Parameterising the build decision during the first phase does not preclude issues raised early in the process from being revisited at a later phase when, for example, requirements and design are formulated in the programming and briefing process. Identifying requirements, developing and discussing design are two other central phases that should be completed before the construction of the building begins. During later phases of the process, when the construction has been completed, the building will be handed over and put into use. At a basic level, construction projects can therefore be said to have five overall phases: (1) the feasibility study, (2) the programming phase, (3) the design phase, (4) the construction phase and (5) the commissioning phase (Clausen, 2002; Storvang, 2012). New designs or changes may be introduced during the different phases, and altered user requirements need to be incorporated into the construction. Guzman (2013, p. 9) describes this process as "emphasising the primacy of emergent and contingent actions, the changing nature of context and settings and the central role of improvisation, negotiation and persuasion". So the phases of the construction process do not necessarily progress in a linear, straightforward manner but should been seen as a continuous learning process concerning the issues at stake (Lê \& Brønn, 2007; Love, Huang, Edwards, \& Irani, 2004; Scarbrough, Swan, Laurent, Bresnen, Edelman, \& Newell, 2004).

On the other hand, the focus of the process will undoubtedly change over time, and different phases of a construction project exist. Several stakeholders are involved in developing new solutions in the construction industry (Love et al., 2004; Newcombe, 2010). These stakeholders' aims and interests may run in parallel or opposite directions to each other. At the same time, stakeholders can have complementary as well as competing competences. As an example, architects and engineers each not only hold distinct competences but also have overlapping ones. These two particular stakeholders may compete or collaborate to lead the same tasks; therefore, aligning the tasks of different stakeholders may present a challenge (Corsaro \& Snehota, 2011). If alignment to some extent is not achieved, it may be difficult to continue with the project.

\section{The role of the facilitator}

A facilitator is often engaged in construction industry projects to attain some degree of organisation among the activities to be carried out as well as a strategy for how and when in the process to conduct those activities (Thomson et al., 2012; Yang, Shen, Bourne, Ho, \& Xue, 2011). The focus of the facilitator is to move the project forward (Thyssen et al., 2010), but at the same time, his or her role is also to enable stakeholders to be engaged and motivated and to express and develop their ideas (Grinyer, 1992). In this sense, facilitation is leading without taking direct control 
(Bens, 2008). A facilitator's job is therefore to enable others to assume responsibility and take the lead, which makes the role of facilitator pivotal in construction projects.

Facilitating is defined as assisting and enabling (Hogan, 2007). What needs assistance and enablement depends on the contingencies. In other words, there is a need to identify the contingencies and steps that could be taken in order to allow a particular construction project to progress. Each construction project has a purpose; for example, construction might be undertaken to provide a family with housing, to create a shelter for goods or to offer an opportunity for people to gather together for various events. A purpose might not be completely clear at the outset; it may evolve over time and become more detailed or shift as the possibilities expand and different considerations are reviewed. Changes in purpose can lead to changes in a construction project's direction (Gish, Clausen, \& Hansen, 2009; Storvang \& Clarke, 2014). To some extent, the purpose of a construction project describes the project, but construction projects may also have different aims for novelty (Håkansson \& Ingemansson, 2013). Based on the above background facilitation is about understanding what tasks the stakeholders have been taken on them and what needs they have (Wilson, Harnish, \& Wright, 2003) - or, if the stakeholders are not aware of their needs, then it's about helping them navigate through a process where they can learn from each to develop their needs or can gain knowledge about what is possible and what is not (Paludan, 2010). The facilitator must be aware of what the purpose is and how it may be developing in order to be able to help move a project forward in collaboration with different stakeholders.

As construction projects are not carried out in isolation but through the involvement of various stakeholders, understanding the resources and competences of these stakeholders is essential to achieving a project's goals (Freytag \& Ritter, 2005; Håkansson 1987). At a basic level, a number of stakeholders are involved in the process: the client, the user, the architect, the engineer and the consultant. The client and the user may in some construction projects be the same stakeholder, but are not necessarily so if the client is a developer. The involvement of specialists also varies according to the purpose of the project. Different purposes require different resources and competences from the specialists involved. Architects, engineers, consultants, client advisors, contractors and builders are examples of specialists who hold potentially needed resources and competences. For this reason, the facilitator must also be aware of what resources and competences are needed and available (Wilson et al., 2003).

Selecting the right team of specialists for an individual project is a complex task, and the evolution of a project's purpose, design, budget and other fundamentals as it moves forward can compound the complexity. For this reason, it is often beneficial to facilitate the process in a way that includes the involvement of specialists and takes the aims and interests of the client and users into account. Other stakeholders such as building authorities may have political interests that need to be taken into account in order to satisfy regulation and permit requirements. Under such contingencies, the competence to act expediently as a facilitator is crucial. Therefore, the facilitator has to know how the organisation of the construction process takes place (Wilson et al., 2003). 


\section{Construction project development over time}

As construction projects develop over time, activities are carried out at different phases according to the overall purpose of the project. To carry out these activities, specific competences are needed. Each stakeholder has a particular role in the project, and this role is related to the stakeholder's professional expertise. Although stakeholders' roles may change over time, the roles themselves are dynamic and contain processual aspects that derive from given access to resources (Öberg, 2010). Each stakeholder provides resources necessary to solve tasks in the construction process. Interaction between stakeholders during the process helps to develop the stakeholders' roles (Medlin \& Saren, 2012). Stakeholders either know how to solve a problem at hand or learn how tasks might be solved as resources are re-combined (Håkansson and Ford, 2002). In the interaction process, stakeholders may take advantage of their current position while also striving to forge new roles in line with the aims, competences and purpose of the project (Anderson, Havila, Andersen, \& Halinen, 1998). In other words, roles are taken and roles are made in the interaction process (Biddle 1986).

How a role is played depends on the nature of the role that needs to be played (Goffman, 1983) as well as on the values each actor brings to the process (Saarijärvi, Kannan, \& Kuusela, 2013). Depending on the contingencies, a user can play different roles, testing or judging a construction project while also being part of the innovation process (Öberg, 2010). In the same way, the role of the facilitator may shift over time depending on the phase of the construction project and the tasks at hand. The dynamics of a construction project can be understood through the specific "position-androle" that links stakeholder positions and roles in the network (Anderson et al., 1998). The actor is said to take-on-activities and make-up-activities and this "constitutes the dynamics in a business network" (Anderson et al., 1998, p.172). In other words, different actors bring in different resources and competences in the construction process over time as they interact in the attempt to solve any problems at hand. With these varying elements at play, the role of the facilitator is to align the actors' use of resources and competences to achieve the goals of the construction project. Facilitation is about both taking a role (realising what is expected) and making a role (developing it further) as it may not be clear from the start where a construction project is heading. This is due to that a particular specification can have various solutions depending on the interpretation of it. But even when detailed plans for construction projects exists it is not all that clear "where construction projects are heading" because problems and possibilities may arise as technical, material or contractor related.

In the attempt to reveal the dynamic and processual aspects of the facilitator's role, an in-depth analysis can create the foundation for understanding the contingencies under which these aspects take place. The facilitator's role seems pivotal throughout the several phases of a construction project, underscoring the rationale for emphasising the competences needed, tasks performed and challenges of acting as a facilitator.

This leads to the question: what is already known about the role of the facilitator in such processes? Above we have described and connected facilitation to role theory. Facilitation is said to be about role-taking and role-making over time under various 
contingencies or, in other words, about the specific "position-and-role" that links stakeholder positions and roles in the network. As only limited knowledge exists in construction literature about the facilitator role, we look at other management areas. In particular, we have focused on management theories concerning alignment of stakeholders' interests and facilitation. Within cluster theory (Christensen \& Stoerring, 2012; Ingstrup, 2013), not only has there been a call to gain more knowledge about the facilitator role, some insights also have been gained about the facilitator (Sydow, Lerch, Huxham, \& Hibbert, 2012). Ingstrup (2013) developed a conceptual model for investigating the roles and purposes of cluster facilitators. This conceptual model describes the roles, purposes/goals, activities, attributes and competences of the facilitator. As facilitation, based on this understanding of the facilitator, comes close to our understanding, we apply this understanding of the facilitator role as a part of our theoretical lens.

In the following, we will, therefore, apply a contingency-based view on construction projects in which we look for:

- construction projects that hold different purposes

- particular issues that are at stake and expected to evolve over time

- competences and resources that are needed to solve the various issues that will emerge

- the demand for different types of facilitation to create alignment during the process.

In particular, we look for how the facilitator tries to align actors' problem understanding and problem solving as he or she gradually learns how the purpose of the project can be served, what resources and competences needs to be combined and how the construction process can be organised. Construction projects are viewed from a network perspective (Ford \& Håkansson, 2006; Håkansson 1987), offering possibilities as well as limitations for acting as a facilitator. Stakeholders bring in different resources, which can be combined and re-combined in a number of ways. Different solutions can be generated in the network, a credit to the competences available within the network, but idea generation depends on previous choices and other obligations of the stakeholders (Håkansson \& Waluszewski, 2007). Construction projects build on a number of relationships that emerge over time and, through this, develop their own histories under particular contingencies. "The history that develops is a product of many factors including the prior history of the participants, the aims and orientations of the participants, the sequences of events taking place, the impacts of connected relations and events, as well as more general market and environmental conditions" (Wilkinson, 2008, p. 100). Summing up; to understand the analysis of the empirical data (3 cases) we using a phase optic, Instrups conceptualisation of the facilitator role and a network framework consisting of five factors proposed by Håkansson and Ford (2002) and re-fined by Biggermann (2012). Due to the framework, interaction among actors is affected by: (a) knowledge gained from other relationships, (b) earlier events in the relationship, (c) current events in the relationship, (d) expectations of the future and (e) events in other networks. 


\section{Methodology}

To highlight central aspects of the facilitation role in the construction industry under different contingencies, three case studies have been conducted. A case study approach was chosen due to the notion that "the interaction between a phenomenon and its context is best understood through in-depth case studies" (Dubois \& Gadde, 2002 , p. 554). Case studies are a unique investigative method that allows the researcher to build and use understandings of an empirical phenomenon with a view to developing theory (Harrison \& Easton, 2004). The cases seek to illustrate what facilitation is and how it varies across different contingencies.

The three cases represent maximum variation in terms of functionality, usability and user groups according to the number of users involved and whether users are known, unknown or a mixture of identified and unidentified users (Miles and Huberman, 1994). The three cases include: (a) a housing project involving an extension to a single-family house, (b) a leisure project involving guest houses and (c) an office building complex.

Some of the projects in the cases have more than one purpose; the guest house project includes working spaces for employees, and the office building complex also includes apartments. All three cases reveal unique, facilitated processes that can shed light on the role of facilitation in construction processes and how this role can vary across different contingencies.

A total of 11 semi structured in-depth interviews with professionals and users/clients were conducted and included open-ended questions about stakeholder involvement in the process including where, when, who and why they were involved. Each interview was recorded, transcribed, and coded in themes in order to strengthen the accuracy of the case study findings. Additional informal discussions were also held with staff, craftsmen, developers, real estate agents, and board members to support the findings.

In the case of the guest houses some of the staff architects, the engineer, the chairman of the board and the daily manager of the guest houses were also interviewed. Notes and observations from a board meeting and various other project meetings where one of the authors participated has been included in the data collected. Four user portraits were made based on interviews and observations by one of the researchers. The user portraits should serve as inspiration for the client organisation and the architects as well as for three workshops facilitated by one of the researchers. In this particular case the architects had already facilitated a workshop at a board meeting, but one of the researchers from this study was asked to take the role of facilitator in three additional workshops, which were held over a period of three month alongside the development of the project.

In the single-family house case one of the researchers made observations based on interviews with users and professionals but also made additional observations and informal interviews on site during the construction period as well as additional interview after the users had taken over the project. 
In the case of the office building interviews and conversations were made with the architect and the real estate agency that also in this case represented the user perspective since they themselves were a part of the client and user organisation.

All the cases also included secondary data from company project reports, prospects, internal documents, design material, drawings, articles from non-scientific journals, newspapers and web pages related to the development of the projects and the organisations involved to support the findings.

The purpose of presenting the cases is not only to highlight the way in which facilitation changes over time, causing various challenges, but also to develop theories about facilitation. An improved understanding of how and to what extent stakeholders align with each other in order to be able to combine and re-combine resources is needed. As Corsaro and Snehota phrase it, "[T]here is still much space for further research" (2011, p. 1051).

\section{Three cases}

The following three cases illustrate how the facilitator's role can change during the construction process, how the cases differ relative to the extent of user and stakeholder involvement, examples of how alignment is achieved and how the cases apply at different phases of the construction genesis.

\section{Extension to an existing house}

The first case involves a construction project for a single-family house. The family had grown from three to four members and they wanted more space. The family had aditionally experienced problems with acoustics from the existing open plan of the house and therefore they wanted to alter the spaces in the existing house as well. The family contacted an architectural firm to develop the project for them, but the project that they applied for was refused planning permission from the authorities. They then hired a new architectural firm, but the architect assigned to the project, who was one of the partners in the firm, withdrew from the company shortly after they had started redrawing the project, leaving the family with yet another new architect.

Following this rough start, the family decided to assign the role of project facilitator entirely to the architect instead of trying to perform the job themselves. The tasks for the architect was then to explore what was feasible to build as well as to investigate what was possible to build while aligning with the authorities, neighbours, builders and other stakeholders. Part of the reason for this decision was that the family realised that they did not have the necessary skills to perform the tasks themselves. Another part of the reason was that they had no desire to spend the considerable time and energy necessary to familiarise themselves with all the professional and technical decisions that would need to be made throughout the project.

The family knew beforehand that building a new extension could be complicated because they wanted to build right up to the boundary they shared with some of the neighbours. Another complication involved a neighbour's old dispute with the previous owner of the house.

To ensure the project would be successfully navigated through the regulatory process with no objections from the neighbours, a dialogue with the neighbours was 
initiated to mediate and negotiate problems and their possible solutions. The family met with the neighbours individually to find common values and secure their acceptance of the project. During negotiations, the architect gave the family guidance and advice regarding changes and supported the family with alterations of the drawings. The architect also prepared new visualisations of alternatives to support the family's dialogue with the neighbours.

In the construction phase of the project, the architect helped the family facilitate some of the problems concerning delays and poorly done work by some of the subcontractors and helped to find suitable subcontractors.

The family's requirements to the house changed during the process as they realised new possibilities, and during the construction of the building, they discovered that they were expecting a new baby, which resulted in yet another change in the project layout. In order to accommodate all the new user requirements, the facilitator had to visualise new possibilities for the family while aligning the requirements just before commissioning.

The entire process was coordinated by the architect, including the conducting of feasibility studies in relation to the regulatory process, the specifying of user requirements in the programming of what was to be built, the designing of the building, the guiding of construction-related decisions involving other consultants and the handling of final considerations in relation to the commissioning of the building. The architect had many roles during the process, including negotiator, designer, adviser, consultant, project manager and meeting moderator, and all these roles required different competences as the facilitator of the process.

This case revealed a situation in which the whole construction process was managed entirely by the facilitator. A primary task for the facilitator was to consider all the different concerns and aims of the stakeholders (the family's requirements, the authorities' regulations, the neighbours' objections, the work of the subcontractors and craftsmen, etc.) during the various phases in the construction process and align them in order to find possible solutions for the project. In order to do this successfully, the facilitator had to change his role during the process.

\section{Guest houses}

The second case involves the development of guest houses in connection to a conference, exhibition and education centre. The facilities had been established a couple of years earlier as a centre for knowledge on climate and environmental activities. Shortly after the centre was developed, an idea was presented to extend the activities with some guest accommodations in which scientists and environmentally concerned nongovernmental organisation visitors could stay while they participated in some of the activities at the centre.

The client organisation asked the architects who originally designed the centre to offer some suggestions for what the guest houses should contain. The architects invited the organisation's board and some local key stakeholders to a meeting to discuss the guest houses. At this meeting, the architects presented some of the initial ideas and invited the stakeholders to comment with further input. During the meeting, it was agreed to form a project group consisting of the manager of the centre, a project man- 
ager from the centre, the chairman of the board and the architects (a design director, a project manager and a project architect). The architects were also asked to find an energy engineering company to advise the project group on the development of energyefficient guest houses. The project group was responsible for developing the project, and the architects and the consultants were then tasked with proposing a concept, design and layout for the guest houses.

Once some ideas had been developed, the architects and the consultants presented a project proposal to the manager of the centre, the project manager from the centre and the chairman of the client organisation's board. Because of the professional layout and quality of the drawings presented, it appeared as if the project was almost ready for construction. However, the architects pointed out that it was still being developed.

Although everybody agreed that the project needed to be developed quickly because of the possibility of some regional funding for a feasibility study, the client felt uncertain about the process and about making quick decisions with very little input except for the architects' ideas for the project. The chairman of the board suggested involving some users in the development of the project, and while the architects as facilitators were reluctant to this suggestion because of the timing issues and the fear of such an open process, it was agreed that a couple of workshops with a wider range of users and other stakeholders would be conducted. Three workshops were held between users and professionals while the architects and the consultant continued to develop the project further.

It was agreed that the workshops would be facilitated by one of the authors a user-involvement researcher. In the workshops, the users and the professionals worked together by using different design and idea generating methods to communicate across professional boundaries and levels of knowledge about the development and values of the project.

The workshop discussions led the manager of the centre to have further doubts about the benefits of the guest houses to the centre. The manager and the chairman of the board also realised that there might be too many unresolved issues regarding how the accommodations would be run, the lack of hotel management experience and guest house services, the handling of maintenance and user requests and the relation the guest houses would have to other activities at the centre and to other local accommodation development projects. It became clear that these matters had not been sufficiently investigated and clarified. It was therefore decided to postpone the process until further evaluation of whether there was a sufficient need for the development of the guest houses.

In this case, the architects had a central role as the project facilitators. The architects were involved in the project from the start of the process, facilitating the investigation and exploration of what to build as well as the development of the brief for the programming of the project.

This project highlighted a number of potential challenges facing both the facilitator and the facilitated process. Seen in retrospect the aim of the project was according to the chairman of the board, the manager of the centre and the architects not clear 
from the start and the propose and need for guest houses had not been properly evaluated. In addition, the architects had a personal interest in initiating grand environmental and energy-efficient projects and, therefore, were perhaps reluctant to take suggestions from others. Also, due to the rushed nature of the project, the presentation of the proposal to the project group and the members of the board resembled a sales speech, although that might not have been the architects' intension. During the process, it quickly became evident that the project potentially had many more stakeholders with operational, political, local and other user interests and that a number of questions remained unsolved, casting doubt as to whether the project was feasible.

\section{Office building complex}

The third case involves a commercial building complex that evolved as a developer project. The project was initially conceived as a shared facility that would host a variety of business enterprises, such as a restaurant, large meeting rooms and a gym and locker room. Although designed as an office building, the complex was also intended to accommodate activities 24 hours a day. In this way, it would be possible for local residents to use the building's facilities outside working hours. For example, residents might use the fitness room, meeting rooms and the restaurant, but the complex could also be used for lectures and exhibitions. The idea was that the building would be able to offer activities to the surrounding community in what was a new area of urban development.

Although the companies that were going to be the future users and tenants of the building were not all known at the outset of the project, some of them had been identified. For example, the architect hired to develop the project was also expected to be one of the future tenants. Many of the others tenants of the building were also companies related to the building industry, such as an engineering company, a building consultant and a real estate agent. They saw this project as an opportunity for their companies to collaborate and create more business by working closer together. Because of the companies' intensions to work closer together and attract the right users, the architects were asked to be the facilitators in a user-involvement process. During this process, the future users were invited to bring in their own personal requirements on the development.

To promote stakeholder participation, various meetings and workshops were held to involve the future tenants in the development of the project. Because of the many user and stakeholder interests, the developer's ideas, the economic framework and the strong political interests in a new high-status urban development, establishing the right network around the development and finding the right users to involve required extra time and additional idea generation as a part of the process before the architects could start designing the building. According to the architects it required that they for a longer period of time than usual in the programming as facilitators remained open to new input and suggestions from users while also managing the process of sometimes taking control of it by making conclusions and closing the group discussions.

Another role of the facilitators in this process was to try and address conflicts and other misalignments between the different interests in order to keep the group together and to sometimes find solutions that could align the stakeholders and their various 
interests. The facilitators task were therefore at times motivating the stakeholders to find common solutions, bringing in new knowledge and insights in order to energise the development of the process in order to keep the stakeholders working together.

As the project facilitators, the architects took on several roles throughout the process, acting as concept developers, project managers, facilitators, future users of the building and, of course, architects. They were involved from the start of the project, helping to identify the various uses of the building, conducting the feasibility studies, facilitating the requirement workshops and helping to make decisions on what to build. They also played a key role in the programming and design phases. But the project came to a halt in the construction phase as the task of implementing the various-use concept proved impossible. In addition, the developers had problem raising sufficient funding and eventually also had trouble securing enough tenants that would fit the project.

The roles of the facilitator in this case was not only to align interests from different user companies as tenants (some known and some not known) but also to align different user groups (one representing firms using the building for business activities during the daytime and another representing individuals using the building for recreational purposes during the evening hours). This case also demonstrated a special challenge in that the facilitators themselves were users and therefore had a personal interest in the project as well.

\section{Discussion}

As described in the above discussion of the three cases, each of the construction projects proceeded differently. This fits with our understanding of how construction projects proceed as processes will never be fully linear because a project can evolve by moving back and forth. Particularly when problems and conflicts arise, it is sometimes necessary to step back to an earlier phase of a project and adjust elements while also continuing to move forward on a higher level to get the project done. Due to the network framework applied (Håkansson \& Ford, 2002; Biggermann, 2012) and based on previous research by Ingstrup (2013) that developed a conceptual model for investigating the roles and purposes of cluster facilitators, we propose to break down the construction process into basic phases and analyse how the roles of the facilitator changes in response to activities that take place throughout the course of that process, as illustrated in the three cases shown in the tables below (see Tables 1, 2 and 3).

In the case of the extension to the single-family home, the entire process was facilitated by the architect, including the conducting of feasibility studies in relation to the regulatory process, the specifying of user requirements in the programming of what was to be built, the designing of the building, the guiding of construction-related decisions involving other consultants and the handling of final considerations in relation to the commissioning of the building. Faced with many tasks and a high degree of misalignment, the facilitator's role changed throughout the process as he sought to understand the problems and help align the stakeholders in order to find solutions. The facilitator was required to be explorative, investigative and engaged in value-based dialogue on what created meaning, functionality and design in the first phases, creative and innovative in the design phase, directorial in the construction phase and protec- 
tive in the commissioning phase, creating comfort round the client family before they took over the house.

Table 1: Role of the facilitator in different phases of construction of an extension to a singly-family house

\begin{tabular}{|c|c|c|c|c|c|}
\hline Phases & $\begin{array}{l}\text { Feasibility } \\
\text { study }\end{array}$ & Programming & Design & Construction & Commissioning \\
\hline $\begin{array}{l}\text { Characteristics } \\
\text { of stage }\end{array}$ & $\begin{array}{l}\text { Decisions on } \\
\text { whether to } \\
\text { build }\end{array}$ & $\begin{array}{l}\text { Requirements, } \\
\text { formulations and } \\
\text { idea generation }\end{array}$ & $\begin{array}{l}\text { Decision on } \\
\text { what to build }\end{array}$ & $\begin{array}{l}\text { Realisation of } \\
\text { construction pro- } \\
\text { ject }\end{array}$ & $\begin{array}{l}\text { Handover and use } \\
\text { of building }\end{array}$ \\
\hline $\begin{array}{l}\text { The role of the } \\
\text { facilitator }\end{array}$ & $\begin{array}{l}\text { Investigating } \\
\text { and exploring }\end{array}$ & $\begin{array}{l}\text { Mediating in a } \\
\text { value-based dia- } \\
\text { logue }\end{array}$ & $\begin{array}{l}\text { Creating and } \\
\text { thinking outside } \\
\text { the box }\end{array}$ & $\begin{array}{l}\text { Leading the pro- } \\
\text { cess of the con- } \\
\text { struction }\end{array}$ & $\begin{array}{l}\text { Creating comfort in } \\
\text { the project in order } \\
\text { to live up to the } \\
\text { client family } \\
\text { expectations }\end{array}$ \\
\hline $\begin{array}{l}\text { Understanding } \\
\text { of the problem }\end{array}$ & $\begin{array}{l}\text { What was } \\
\text { possible to } \\
\text { build and } \\
\text { what was not? } \\
\text { There were } \\
\text { problems } \\
\text { about building } \\
\text { too close to } \\
\text { the neigh- } \\
\text { bours. }\end{array}$ & $\begin{array}{l}\text { Getting a deeper } \\
\text { understanding of } \\
\text { what to build. The } \\
\text { client had inherit- } \\
\text { ed an old dispute } \\
\text { from the previous } \\
\text { owner of the } \\
\text { house. }\end{array}$ & $\begin{array}{l}\text { Getting as } \\
\text { much out of the } \\
\text { project as pos- } \\
\text { sible under the } \\
\text { given circum- } \\
\text { stances by } \\
\text { thinking outside } \\
\text { the box and } \\
\text { pushing the ar- } \\
\text { chitectural lim- } \\
\text { its to the utmost } \\
\text { by creating new } \\
\text { ideas for the } \\
\text { project }\end{array}$ & $\begin{array}{l}\text { How to get the } \\
\text { project built by } \\
\text { understanding } \\
\text { the technical so- } \\
\text { lutions and find- } \\
\text { ing the right con- } \\
\text { tractors to do the } \\
\text { job }\end{array}$ & $\begin{array}{l}\text { What are the final } \\
\text { obstacles in the } \\
\text { project for it to be a } \\
\text { success for the fu- } \\
\text { ture users? }\end{array}$ \\
\hline $\begin{array}{l}\text { Activities of the } \\
\text { facilitator }\end{array}$ & $\begin{array}{l}\text { Consulting } \\
\text { and gathering } \\
\text { input provided } \\
\text { by authorities } \\
\text { and the client }\end{array}$ & $\begin{array}{l}\text { Gathering input } \\
\text { provided by au- } \\
\text { thorities, neigh- } \\
\text { bours and the cli- } \\
\text { ent }\end{array}$ & $\begin{array}{l}\text { Generating } \\
\text { ideas and cre- } \\
\text { ating visualisa- } \\
\text { tions and mod- } \\
\text { els to explore } \\
\text { the project }\end{array}$ & $\begin{array}{l}\text { Closing contrac- } \\
\text { tors and making } \\
\text { decisions when } \\
\text { choosing the } \\
\text { right level of de- } \\
\text { tailing }\end{array}$ & $\begin{array}{l}\text { Finding last-minute } \\
\text { solutions and alter- } \\
\text { natives by rearrang- } \\
\text { ing things }\end{array}$ \\
\hline $\begin{array}{l}\text { Solution to the } \\
\text { problem }\end{array}$ & $\begin{array}{l}\text { Gathering in- } \\
\text { formation, lis- } \\
\text { tening to the } \\
\text { different } \\
\text { stakeholders } \\
\text { and creating } \\
\text { trust among } \\
\text { stakeholders }\end{array}$ & $\begin{array}{l}\text { Negotiating with } \\
\text { authorities, } \\
\text { neighbours and } \\
\text { the client about } \\
\text { their oppositions }\end{array}$ & $\begin{array}{l}\text { Selling the pro- } \\
\text { ject to the client } \\
\text { and inviting } \\
\text { neighbours } \\
\text { over for coffee } \\
\text { to get them to } \\
\text { support the pro- } \\
\text { ject }\end{array}$ & $\begin{array}{l}\text { Guiding and } \\
\text { keeping control } \\
\text { over the contrac- } \\
\text { tors, monitoring } \\
\text { the scheduling } \\
\text { and quality of the } \\
\text { work and making } \\
\text { decisions when } \\
\text { needed }\end{array}$ & $\begin{array}{l}\text { Selling new oppor- } \\
\text { tunities and alterna- } \\
\text { tives for the future } \\
\text { users }\end{array}$ \\
\hline
\end{tabular}


Table 2: Role of the facilitator in different phases of construction of guest houses

\begin{tabular}{|c|c|c|c|c|c|}
\hline Phases & $\begin{array}{l}\text { Feasibility } \\
\text { study }\end{array}$ & Programming & Design & Construction & Commissioning \\
\hline $\begin{array}{l}\text { Characteristics } \\
\text { of stage }\end{array}$ & $\begin{array}{l}\text { Decisions on } \\
\text { whether to } \\
\text { build }\end{array}$ & $\begin{array}{l}\text { Requirements, } \\
\text { formulations and } \\
\text { idea generation }\end{array}$ & $\begin{array}{l}\text { Decision on } \\
\text { what to } \\
\text { build }\end{array}$ & $\begin{array}{l}\text { Realisation of } \\
\text { construction pro- } \\
\text { ject }\end{array}$ & $\begin{array}{l}\text { Handover and use } \\
\text { of building }\end{array}$ \\
\hline $\begin{array}{l}\text { The role of the } \\
\text { facilitator }\end{array}$ & $\begin{array}{l}\text { Investigating } \\
\text { and exploring }\end{array}$ & $\begin{array}{l}\text { Mediating in a } \\
\text { value-based dia- } \\
\text { logue }\end{array}$ & & & \\
\hline $\begin{array}{l}\text { Understanding } \\
\text { of the problem }\end{array}$ & $\begin{array}{l}\text { What would be } \\
\text { relevant for the } \\
\text { client to build, } \\
\text { and how could } \\
\text { the project be } \\
\text { developed as a } \\
\text { state-of-the-art } \\
\text { answer to cli- } \\
\text { mate issues? }\end{array}$ & $\begin{array}{l}\text { The client had } \\
\text { doubts about the } \\
\text { feasibility of the } \\
\text { project and its } \\
\text { value to the exist- } \\
\text { ing centre. }\end{array}$ & & & \\
\hline $\begin{array}{l}\text { Activities of the } \\
\text { facilitator }\end{array}$ & $\begin{array}{l}\text { Closed the de- } \\
\text { velopment ac- } \\
\text { tivities together } \\
\text { with a group of } \\
\text { specialists }\end{array}$ & $\begin{array}{l}\text { The chairman } \\
\text { asked an outsider } \\
\text { facilitator to con- } \\
\text { duct a user- } \\
\text { involvement } \\
\text { study. }\end{array}$ & & & \\
\hline $\begin{array}{l}\text { Solution to the } \\
\text { problem }\end{array}$ & $\begin{array}{l}\text { The project ar- } \\
\text { chitects as fa- } \\
\text { cilitators de- } \\
\text { veloped a } \\
\text { state-of -the- } \\
\text { art project and } \\
\text { sold the idea to } \\
\text { the client. }\end{array}$ & $\begin{array}{l}\text { Three user- } \\
\text { involvement work- } \\
\text { shops were held } \\
\text { to debate values } \\
\text { of the project. }\end{array}$ & & & \\
\hline
\end{tabular}

In the case of the guest house project, the architects had a central role as project facilitators. They were involved in the project from the start of the process, investigating and exploring what to build and facilitating the development of the brief for the programming of the development in the form of a pre-project. The pre-project was developed in collaboration with other experts but misaligned with the client's values. The architects, acting as facilitators, not able to investigate and unfold the feasibility of the project and were unsuccessful in sufficiently aligning user and other stakeholder requirements in the pre-project. Since it was realised that the right stakeholders were not involved and that the viewpoints of the stakeholders who were involved were not aligned, the project came to a halt in the programming phase because further investigations into the feasibility of the project needed to be conducted. 
Table 3: Role of the facilitator in different phases of construction of an office building complex

\begin{tabular}{|c|c|c|c|c|c|}
\hline Phases & $\begin{array}{l}\text { Feasibility stu- } \\
\text { dy }\end{array}$ & Programming & Design & Construction & $\begin{array}{l}\text { Commission- } \\
\text { ing }\end{array}$ \\
\hline $\begin{array}{l}\text { Characteristics } \\
\text { of stage }\end{array}$ & $\begin{array}{l}\text { Decisions on } \\
\text { whether to build }\end{array}$ & $\begin{array}{l}\text { Requirements, } \\
\text { formulations and } \\
\text { idea generation }\end{array}$ & $\begin{array}{l}\text { Decision on } \\
\text { what to build }\end{array}$ & $\begin{array}{l}\text { Realisation of } \\
\text { construction } \\
\text { project }\end{array}$ & $\begin{array}{l}\text { Handover and } \\
\text { use of building }\end{array}$ \\
\hline $\begin{array}{l}\text { The role of the } \\
\text { facilitator }\end{array}$ & $\begin{array}{l}\text { Investigating and } \\
\text { exploring }\end{array}$ & $\begin{array}{l}\text { Mediating in a val- } \\
\text { ue-based dialogue }\end{array}$ & $\begin{array}{l}\text { Creating and } \\
\text { thinking out- } \\
\text { side the box }\end{array}$ & $\begin{array}{l}\text { Leading the } \\
\text { process of the } \\
\text { construction }\end{array}$ & \\
\hline $\begin{array}{l}\text { Understanding } \\
\text { of the problem }\end{array}$ & $\begin{array}{l}\text { How could a de- } \\
\text { velopment pro- } \\
\text { cess be designed } \\
\text { differently to at- } \\
\text { tract new types of } \\
\text { users interested in } \\
\text { alternative uses of } \\
\text { an office building? }\end{array}$ & $\begin{array}{l}\text { How could an of- } \\
\text { fice building be de- } \\
\text { signed to accom- } \\
\text { modate a wide } \\
\text { range of social in- } \\
\text { teraction between } \\
\text { internal and exter- } \\
\text { nal users? }\end{array}$ & $\begin{array}{l}\text { Letting users } \\
\text { be a part of } \\
\text { the develop- } \\
\text { ment process }\end{array}$ & $\begin{array}{l}\text { Doing the initial } \\
\text { technical con- } \\
\text { struction draw- } \\
\text { ings and under- } \\
\text { standing the fi- } \\
\text { nancial problem } \\
\text { in the develop- } \\
\text { ment }\end{array}$ & \\
\hline $\begin{array}{l}\text { Activities of the } \\
\text { facilitator }\end{array}$ & $\begin{array}{l}\text { Collaborating with } \\
\text { the client devel- } \\
\text { opers to explore } \\
\text { alternative uses of } \\
\text { the offices and } \\
\text { identify new types } \\
\text { of users }\end{array}$ & $\begin{array}{l}\text { Creating a dia- } \\
\text { logue with possible } \\
\text { users about their } \\
\text { requirements of } \\
\text { the complex as } \\
\text { well as educating } \\
\text { potential users } \\
\text { about the possibili- } \\
\text { ties of sharing } \\
\text { common work } \\
\text { spaces }\end{array}$ & $\begin{array}{l}\text { Co-designing } \\
\text { with users }\end{array}$ & $\begin{array}{l}\text { Advising the cli- } \\
\text { ent in the } \\
\text { search for ten- } \\
\text { ants in order to } \\
\text { be able to start } \\
\text { construction }\end{array}$ & \\
\hline $\begin{array}{l}\text { Solution to the } \\
\text { problem }\end{array}$ & $\begin{array}{l}\text { Identifying a wide } \\
\text { rage of users and } \\
\text { other types of } \\
\text { stakeholders }\end{array}$ & $\begin{array}{l}\text { Collaborating with } \\
\text { multiple stakehol- } \\
\text { ders }\end{array}$ & $\begin{array}{l}\text { Doing the final } \\
\text { design of the } \\
\text { project very } \\
\text { late in the pro- } \\
\text { cess }\end{array}$ & $\begin{array}{l}\text { Making altera- } \\
\text { tions and cost } \\
\text { reductions in the } \\
\text { project to fit a } \\
\text { broader market } \\
\text { demand }\end{array}$ & \\
\hline
\end{tabular}

In the case of the office building complex, the architects were involved from the start of the project in identifying the various uses of the building, conducting the feasibility studies, facilitating the requirement workshops and helping to make decisions on what to build. They therefore played a key role in the feasibility study, programming and design phases. Their primary task during the process was to create alignment among multiple stakeholders' ideas, the client developers' vision and the financial framework. During the construction phase, the project was put on hold due to the global financial crisis. In addition to raising insufficient funds, the client developers failed to secure the number of tenants needed to start construction before the crisis broke, and implementing the concept of an open office facility designed for multiple users proved to be impossible. Now that the economy is picking up, new investors are being sought. 
The findings from our three cases offer some interesting insights into how facilitation takes place under various contingencies over time and is affected by different competences and the influences of and upon other stakeholders (Bygballe et al., 2010; Sense, 2004).

Identifying contingencies is pivotal to understanding how a construction project develops. Each stakeholder plays a particular role based on his or her competences and the purpose for which he or she became involved in a particular project. The competences and aims of each stakeholder can provide both possibilities and limitations for solving problems (Håkansson and Snehota, 1998). As the three construction project case studies revealed, understanding individual stakeholders' contributions and the potential challenges within a particular network is central to the role of facilitator. In the single-family house project, the family's interests could not be taken into account exclusively - there were others' interests at stake as well as building regulations requirements that needed to be met and neighbours that needed to be appeased. In the guest house project, the facilitator was challenged by the various stakeholders' personal interests as well as his own interests in creating a novel portfolio project, compounding the difficulty of aligning the process. Finally, in the office building complex project, the facilitator faced the challenge of playing many roles at the same time. The responsibility of negotiating with already known stakeholders and determining the interests of unknown stakeholders was a burden. Some stakeholders were insiders with private interests, and others were outsiders. Both workspace and recreational users had to share facilities in the same building, and the needs of all somehow had to be accommodated. From these conflicts, a number of issues that are central to understanding the facilitator role become evident (see table 4).

Table 4: Role of the facilitator, competences and activities at different phases of construction

\begin{tabular}{|c|c|c|c|c|c|}
\hline Phases & $\begin{array}{l}\text { Feasibility stu- } \\
\text { dy }\end{array}$ & $\begin{array}{l}\text { Program- } \\
\text { ming }\end{array}$ & Design & Construction & $\begin{array}{l}\text { Commission- } \\
\text { ing }\end{array}$ \\
\hline $\begin{array}{l}\text { Characteris- } \\
\text { tics of stage }\end{array}$ & $\begin{array}{l}\text { Decisions on } \\
\text { whether to build }\end{array}$ & $\begin{array}{l}\text { Requirements, } \\
\text { formulations } \\
\text { and idea gener- } \\
\text { ation }\end{array}$ & $\begin{array}{l}\text { Decision on what } \\
\text { to build }\end{array}$ & $\begin{array}{l}\text { Realisation of } \\
\text { construction pro- } \\
\text { ject }\end{array}$ & $\begin{array}{l}\text { Handover and } \\
\text { use of building }\end{array}$ \\
\hline $\begin{array}{l}\text { The role of the } \\
\text { facilitator }\end{array}$ & $\begin{array}{l}\text { Investigating and } \\
\text { exploring }\end{array}$ & $\begin{array}{l}\text { Mediating in a } \\
\text { value-based di- } \\
\text { alogue }\end{array}$ & $\begin{array}{l}\text { Creating and } \\
\text { thinking outside } \\
\text { the box }\end{array}$ & Leading & $\begin{array}{l}\text { Creating comfort } \\
\text { in the project in } \\
\text { order to live up to } \\
\text { their expectations }\end{array}$ \\
\hline $\begin{array}{l}\text { The compe- } \\
\text { tences of the } \\
\text { facilitator }\end{array}$ & $\begin{array}{l}\text { Hedging and en- } \\
\text { suring that every- } \\
\text { one is heard }\end{array}$ & $\begin{array}{l}\text { Taking an open, } \\
\text { curious and } \\
\text { value-based } \\
\text { approach }\end{array}$ & $\begin{array}{l}\text { Energizing and } \\
\text { motivating }\end{array}$ & $\begin{array}{l}\text { Controlling, clo- } \\
\text { sing and conclu- } \\
\text { ding }\end{array}$ & $\begin{array}{l}\text { Being a visionary } \\
\text { who can see and } \\
\text { communicate } \\
\text { opportunities }\end{array}$ \\
\hline $\begin{array}{l}\text { Activities of } \\
\text { the facilitator }\end{array}$ & $\begin{array}{l}\text { Facilitating stake- } \\
\text { holder and net- } \\
\text { work activities }\end{array}$ & $\begin{array}{l}\text { Facilitating vi- } \\
\text { sions and idea } \\
\text { generation }\end{array}$ & $\begin{array}{l}\text { Removing unne- } \\
\text { cessary } \\
\text { obstacles }\end{array}$ & $\begin{array}{l}\text { Implementation in } \\
\text { organisation }\end{array}$ & $\begin{array}{l}\text { Handing over to } \\
\text { future users }\end{array}$ \\
\hline
\end{tabular}


The role, competences and activities of the facilitator that are described in table 4 build on knowledge gained about how the facilitator acted in the phases in the 3 cases. While making a feasibility study the facilitator in all 3 cases had to make sure the different stakeholders where heard and what the stakeholders saw as important issues where considered. Discussing programming was mainly a task about the value in use the building could give the users with regard to the functionality and design of the building in the 3 cases. The facilitator had in the designing phase to drive process forward through motivating the stakeholders and removing obstacles. I.e. discussing and arguing so that some kind of common ground could be reached and a decision on what to build could be reached. In the construction phase the facilitator in all 3 cases took the lead in the sense that major and minor issues got solved - almost like in a Gant card where tasks where identified, actors and resources assigned for the task and a time table set up. In the final commissioning phase the facilitators role was not only to hand over the building, but also to make sure that the solution was as expected was provided and to stipulate a vision of how the building might be made use of.

According to how the role of the facilitator was chosen it seems that the facilitator was not randomly selected since in all the three cases the facilitator had a history in relation to the project. In the case of the guest houses they had selected the architects since they had design the initial project of the exhibitions centre. At that stage they had in the original project already suggested a possibility for the centre to expand the project with some guest houses in the future. It therefore seemed natural to ask the chief architect to be the facilitator. In the project of the single family house the architect was chosen since the family unwillingly had ended up with a new architect because the architect that they had hired stopped as partner in the architectural company. So he came in a little by coincidence. Luckily the facilitator understood what the family wanted him to do so it ended up as a success although he first had to get to learn about what they wanted from him. In the last case with the office building all the architect was one of the founding users. So all the others in the project already knew and trusted him since they professionally had worked together with him in previously projects.

Looking across the cases facilitation is to a high degree about alignment. In each of the phases, the actors may hold different understandings of "what the problem is" and "what the solution is". The facilitator, therefore, has to grasp how the different stakeholders look at the problem at hand and its solution. Because of fluctuations in alignment, many problems can appear in more than one phase of the process. In order to find solutions to the problems, the facilitator needs to work in different ways (listen, give in, confront, ..) with various stakeholders during the process in order to create alignment. And whether it succeeds for the facilitator to create alignment depends in on the social skills and the ability to create interaction, negotiation and alignment between the other stakeholders in the project.

\section{Conclusion}

This paper contributes to an understanding of the facilitator's role, changes in the facilitator's role over time and the role's importance in construction industry projects under different contingencies (Håkansson \& Ingemansson, 2011). In particular, this 
paper highlights the dynamic nature of facilitators' roles over time in industrial networks.

First, user problems are individual and complex; these problems must be understood in each particular case (Håkansson \& Ingemansson, 2013). The solution to user problems is likely to require a complex offering that can only be defined or developed interactively with the stakeholder (Ritter \& Ford, 2004). The facilitator needed to mediate in all three cases. In the single-family house case, conflicts occurred with the first architect and later between neighbours who had different interests. There were conflicts in the guest house case as the architects and other professionals were reluctant to take in users' perspectives. Acknowledging conflicts is the first step in finding better solutions. This notion is in line with Wilkinson and Young (1994), who found that a certain level of confrontation (and thus conflict) is needed in relationships to allow them to develop further.

Problems and conflicts can be interpreted in a number of ways. Gaps between perceptions of the problem by the client, user, engineer or architect are common (Corsaro \& Snehota, 2011) and may be a hurdle the facilitator must overcome. That said, Bengtson, Ljung, and Hadjikhani (2013) find that every relationship holds behaviour that can lead to instability and crises because of uncertainty, trust and commitments, which means that the facilitator needs to be able to manage these types of situations.

Second, the phase of the construction project matters. Different issues are at stake at each phase of the project, and the facilitator must focus on each particular issue as it arises. Not only will the facilitator have to involve stakeholders to solve the problem, he or she will also need to understand dynamics of events occurring during the different phases. In other words, the facilitator must understand what has to be done in a particular situation when a feasibility study or programming decision must be made. At the feasibility phase, the ability to communicate with the stakeholders seems needed, as both professional and non-professional participants are involved. In the case study involving the extension to the single-family house, it was necessary to identify the needs of the users. In the case study involving the guest houses, understanding and evaluating the fundamental idea of the project was important. The office building complex project presented a clearer task-to evaluate whether an officebuilding complex could have a double purpose. Stakeholders were involved accordingly to make the evaluation possible.

Third, competences are important to establish a dialogue with stakeholders concerning the particulars of a project. Framing a project is essential, and entering into a dialogue about solving particular issues is another task. Different competences was needed at each phase. User needs must be understood or further developed, a task that sometimes calls for the facilitator to develop a stakeholder's communication skills or tacit knowledge that is behind human activities (Guzman, 2013). Client interests must be recognised. Engineers and craftsmen must be included in discussions to identify possible solutions as problems arise. The background and purpose of each of the three projects were different, as were the competences and management knowledge needed to complete them. 
Fourth, at various phases throughout the process, the facilitator to analysed and gained knowledge about what is possible and what is not. The facilitator assisted the process and enabled solutions to be found. Conflicts may come up, but not necessarily be problematic as they can highlight differences in the understanding of "a problem" or "a solution. One way of doing so is by influencing stakeholders to seek some degree of alignment among themselves. Influencing is accomplished by confronting, giving in or re-defining what may be at stake (Ritter \& Ford, 2004; Schön 1983). The process requires analytical skills, which are highly relevant to developing a project with stakeholders, but these skills must be complemented by creative skills concerned with the exploration of "What might be?" The skill of being willing and able to learn, which enables an individual to develop both divergent creative and convergent analytical capabilities as well the synergies between the two, is fundamental to the facilitator's toolbox.

Combining divergent and convergent thinking is a problem-solving approach in which value is created in a human-oriented light. This approach requires tools that enable one to think outside the box, evaluate ideas and build business models through prototype experiments and co-creation processes that enable stakeholders to develop their divergent creative capabilities, their analytical and convergent skills and the synergies between the two. This synergistic development involves focusing on questions such as "What is the purpose for the involvement?" "Who will be involved?" "How much involvement is needed?" and "How should the stakeholder be motivated to participate in the process?" (Roser, DeFillippi, \& Samson, 2013). This managing process also requires a deep focus from the facilitator on identifying and understanding what kind of value is created for whom (Saarijärvi et al., 2013). The values, the purpose of involvement and the relationship between co-creators can change with specific tasks that stakeholders fulfil across particular value-creation processes (Owen, Goldwasser, Choate, \& Blitz, 2008).

Finally, when a person takes on the role of facilitator, he or she should be aware of the possibilities for influencing others. The limits and possibilities of the facilitator's role must be learned along with the construction process (Holmqvist, 2004). Every construction project is different, which makes the role of facilitator even more challenging. The role is defined only to some degree in advance and must therefore be developed and learned over time by the role taker (Biddle, 1986). In this learning process it is not only a question of taken on a role, but also a matter of developing the role. Development or role making is challenging as the role make at least to some extend will have to act in accordance with what is at stake in the particular phase and at the same time bring in elements or issues which can be helpful to move the process forward. As interaction processes between actor and construction can be difficult to plan fully in advance how the role of the facilitator can be difficult to anticipate in advance. In line with this, the three cases presented revealed that the role of facilitator varies a lot depending on the different phases of a construction project and can include investigating, mediating, creating, leading and creating security, among many other activities. Although the aim of each phase may differ, the facilitator will be tasked with achieving alignment in each as well as developing an understanding of the "problem" and/or the "solution". As all aspects of the "problem" and/or "solution" 
was not known in advance how the facilitator role should be played and be developed was something that had to evolve in the situation.

Understanding the impacts of different contingencies and the role played by the facilitator have proved to be a valid research strategy in this instance. Even though construction projects may vary from project to project, certain expectations about competences needed and tasks performed within the construction industry seem to exist. In other words, variance among construction projects seems to some extent to be given with regard to the role of the facilitator. What happens when expectations about competences needed and tasks performed by the facilitator are less clear? This question needs further attention before other dimensions of facilitation might be revealed. A next step could be to investigate facilitation in innovation projects and the impacts of different contingencies on facilitation in order to understand the extent to which the challenges of facilitation identified in this paper are generic across industries.

\section{References}

Anderson, H., Havila, V., Andersen, P., \& Halinen, A. (1998). Position and role-conceptualizing dynamics in business networks. Scandinavian Journal of Management, 14(3), 167-186.

Barney, J. B. (1985). Organizational culture: Can it be a source of sustained competitive advantage? The Academy of Management Review, 11(3), 656-665.

Bengtson, A.; Ljung, A., \& Hadjikhani, A. (2013). Managing stability and crises in business relationship: The case of Ericsson in an emerging market. European Business Review, 25(6), 518-535.

Bens, I. (2008). Facilitation at a glance! Your pocket guide to facilitation (2nd edition). GOAL/QPC (Growth Opportunity Alliance of Lawrence).

Biddle, B.J. (1986). Recent developments in role theory. Annual Review of Sociology, 12(1), 67-92.

Biggermann, S (2012). The essential role of information sharing in relationship development, Journal of Business and Industrial Marketing, 27(7), 521-526.

Bygballe, L. E., Jahre, M., \& Swärd, A. (2010). Partnering relationships in construction: A literature review. Journal of Purchasing and Supply Management, 16(4), 239-253.

Christensen, J.L., \& Stoerring, D. (2012). Facilitating cluster evolution in peripheral regions: The role of clusterpreneurs. In B.T. Asheim \& M.D. Pirelli (eds.), Interactive learning for innovation: A key driver within clusters and innovation systems (pp. 137-160). Houndmills, Basingstoke, Hampshire: Palgrave MacMillan.

Christensen, M. C. (1997), The innovators dilemma: when new technologies cause great firms to fail. Boston, Mass.: Harvard Business School Press.

Christiansson, P., Sørensen, K. B., Rødtness, M., Abrahamsen, M., Riernnann, L. O., \& Alsdorf, M. (2008). User driven innovation in the building process. Tsinghua Science and Technology, 13(1), 248-254.

Clausen, L. (2002). Innovationsprocessen $i$ byggeriet. Fra idé til implementering i praksis. PhD-Thesis, DTU Byg, Danmarks Tekniske Universitet, Kgs. Lyngby.

Corsaro, D., \& Snehota, I. (2011). Alignment and misalignment in business relationships. Industrial Marketing Management, 40(6), 1042-1054.

Dubois, A., \& Gadde, L.-E. (2002). Systematic combining: An abductive approach to case research. Journal of Business Research, 55(7), 553-560.

Eccles, R. G. (1981). The quasifirm in the construction industry. Journal of Economic Behavior and Organisation, 2, 335-357.

Ford, D., \& Håkansson, H. (2006). The idea of interaction. IMP Journal, 1(1), 4-20, available at http://www.impjournal.org/ (accessed 14 March, 2014).

Freytag, P. V., \& Ritter, T. (2005). Dynamics of relationships and networks - Creation, maintenance, and destruction as managerial challenges. Industrial Marketing Management, 34(7), 644-647. 
Gish, L., Clausen, C., \& Hansen, C.T. (2009). A case study of idea work in the early phases of product development. In ICED09: 17th International Conference on Engineering Design (pp. 447-458). Stanford University Press: Stanford, CA.

Goffman, E. (1983). The interaction order: American Sociological Association, 1982 presidential address. American Sociological Review, 1(1), 1-17.

Grinyer, Peter H. (1992). A cognitive approach to facilitating group strategic decision taking: Analysis of practice and a theoretical interpretation, knowledge and policy. The International Journal of Knowledge Transfer and Utilization, 5(3), 26-49.

Guzman, G. (2013). The grey textures of practice and knowledge: Review and framework. European Business Review, 25(5), 429-452.

Håkansson, H. (1987). Industrial technological development: A network approach. Routledge: London, England.

Håkansson, H., \& Ford, D. (2002). How should firms interact in business networks? Journal of Business Research, 55(2), 133-139.

Håkansson, H., \& Ingemansson, M. (2013). Industrial renewal within the construction network. Construction Management and Economics, Vol. 31 No. 1, pp. 40-61.

Håkansson, H., \& Snehota, I. (1998). The burden of relationships or who's next? In Naudé, P., \& Turnbull, P. W. (Eds.), Network dynamics in international marketing (pp. 16-25). Pergamon Press: London.

Håkansson, H., \& Ford, D. (2002). How should companies interact in business networks. Journal of Business Research, 55, 113-139.

Håkansson, H., \& Waluszewski, A. (Eds.), (2007). Knowledge and innovation in business and industry. The importance of using others Routledge: London.

Harrison, D., \& Easton, G. (2004). Temporally embedded case comparison in industrial marketing research. In Fleetwood, S., \& Ackroyd, S. (Eds.), Critical realist applications in organisation and management studies (pp. 179-192). Routledge: London.

Holmqvist, M. (2004). Experimental learning processes of exploitation and exploration within and between organizations: An empirical study of product development. Organizational Science, 15(1), 70-81.

Hogan, C.F. (2007). Facilitating multicultural groups: A practical guide. London: Kogan Page.

Ingstrup, M. (2013). Facilitating different types of clusters. Management Revue, 24(2), 133-150, DOI 10.1688/1861-9908_mrev_2013_02_Ingstrup.

Lê, M. A. T., \& Brønn, C. (2007). Linking experience and learning: Application to multi-project building environments. Engineering, Construction and Arcbitectural Management, Vol. 14 No. 2, pp. 150-163.

Love, P. E. D., Huang, J. C., Edwards, D. J., \& Irani, Z. (2004). Building a learning organization in a project-based environment. Construction Innovation: Information, Process, Management, 4(2), 113-126.

Medlin, C. J., \& Saren, M. (2012). Interaction: Coherence to a future. In Glynn, M. S., \& Woodside, A. G. (Eds.), Advances in business marketing and purchasing. Vol. 18 (pp. 175-192). Emerald: London.

Miles, M. B., \& Huberman, A. M. (1994). Qualitative data analysis - An expanded sourcebook (2nd ed.). Sage: Thousand Oaks, CA.

Newcombe, R. (2010). From client to project stakeholders: a stakeholder mapping approach. Construction Management and Economics, 21(8), 841-848.

Öberg, C. (2010). Customer roles in innovations. International Journal of Innovation Management, 14(6), 9891011.

Owen, L., Goldwasser, C., Choate, K., \& Blitz, A. (2008). Collaborative innovation throughout the extended enterprise. Strategy and Leadership, 36(1), 39-45.

Paludan, T. (2010). Creating spaces of learning. In J. Halse, E. Brandt, B. Clark, \& T. Binder (Eds.), Rebearsing the future (pp 170-174). The Danish Design School Press.

Ritter, T., \& Ford, D. (2004). Interactions between suppliers and customers in business markets. In Håkansson, H., Harrison, D., \& Waluszewski, A. (Eds.), Rethinking marketing: Developing a new understanding of markets (pp. 99-117). Wiley: Chichester, England.

Roser, T., DeFillippi, R., \& Samson, A. (2013). Managing your co-creation mix: Co-creation ventures in distinctive contexts. European Business Review, 25(1), 20-41. 
Saarijärvi, H., Kannan, P. K., \& Kuusela, H. (2013). Value co-creation: Theoretical approaches and practical implications. European Business Review, 25(1), 6-19.

Scarbrough, H., Swan, J., Laurent, S., Bresnen, M., Edelman, L., \& Newell, S. (2004). Project-based learning and the role of learning boundaries. Organization Studies, 25(9), 1579-1600.

Schön, D. A. (1983). The reflective practitioner: How professionals think in action. Basic Books: New York, NY.

Sense, A. J. (2004). An architecture for learning in projects? Journal of Workplace Learning, 16(3), 123-145.

Shen, Q., Li, H., Chung, J., \& Hui, P.-Y. (2004). A framework for identification and representation of client requirements in the briefing process. Construction Management and Economics, 22(2), 213-221.

Storvang, P. \& Clarke, A. H. (2014). How to create a space for stakeholder' involvement in construction. Construction Management and Economics, 32(12), 1166-1182.

Storvang, P. (2012), Brugerinddragelse i Byggeriet - Med Sarlig Fokus på det Arkitekttegnede Boligbyggeri (Doctoral thesis [User Involvment in the Building Industry]). Kolding, Denmark, University of Southern Denmark.

Sydow, J., Lerch, F., Huxham, C., and Hibbert, P. (2011). A silent cry for leadership: Organizing for leadership (in) clusters. The Leadership Quarterly, 22(2), 328-343.

Thomson, D., Kaka, A., Pronk, L., \& Alalouch, C. (2012). The use of freelisting to elicit stakeholder understanding of the benefits sought from healthcare buildings. Construction Management and Economics, 30(4), 309-323.

Thyssen, M. H., Emmitt, S., Bonke, S., \& Kirk-Christoffersen, A. (2010). Facilitating client value creation in the conceptual design phase of construction projects: A workshop approach. Architectural Engineering and Design Management, 6(1), 18-30.

Van Sell, M., Brief, A.P., \& Schuler, R. (1981). Directions for future research role conflict and role ambiguity: Integration of the literature and directions for future research. Human Relations, 34(1), 43-71.

Wilkinson I. (2008). Business relating business: Managing organizational relation and networks. Edward Elgar: Abingdon, United Kingdom

Wilkinson, I. F., \& Young, L. C. (1994). Business dancing - The nature and role of interfirm relations in business strategy. Asia-Australia Marketing Journal, 2(1), 67-79.

Wilson, P., H., Harnish, K., \& Wright, J. (2003). The facilitative way. Leadership that makes the difference. TeamTech Press.

Yang, J., Shen, G. Q., Bourne, L., Ho, C. M.-F., \& Xue, X. (2011). A typology of operational approaches for stakeholder analysis and engagement: Findings from Hong Kong and Australia. Construction Management and Economics, 29(2), 145-162. 